\title{
Effect of Honeybee (Apis mellifera L.) Pollination on Yields and other Yield Parameters of Watermelon (Citrullus Lanatus L.)
}

\author{
Taye Beyene* Mekonen Woldatsadik \\ Oromia Agricultural Research Institute, Adami Tulu Agricultural Research Center, Zeway, Ethiopia
}

\begin{abstract}
Insect pollinators are essential in increasing seed set of many flower and fruit crops; as well as the quality of seed or fruit, early flowering, oil content, pyrethrin content, rubber content and the amount of lavender oil. As a result the need for insect pollination is becoming popular by agricultural community to increase the productivity of crops. This study was conducted at Adami Tulu Agricultural Research Center for three successive years to see the role of managed honeybee pollination on yields and other yield parameters of watermelon (Citrullus lanatus L.) and to identify potential pollinators of watermelon other than honeybees. To this effect, nine plots of 4 by $6 \mathrm{~m}$ of land were prepared. The plots were grouped into three treatment groups with three replications. In the first group plots caged with mesh for intensive pollination. The second plots were caged with mesh without any pollinator, while the third plots were left open to be pollinated under natural conditions. The results of the study showed that the yield obtained from plots pollinated by honeybee was superior with the mean yield of $57472 \mathrm{~kg} /$ hectare followed by plots left open under natural conditions with the mean yield of $38361 \mathrm{~kg} /$ hectare. The lowest mean yield of $22472 \mathrm{~kg} /$ hectare was recorded for the plots excluded any pollinator. The results also revealed that honeybee pollination increases watermelon fruit yield by $91 \%$ over natural pollination. Therefore, moving honeybee colonies to watermelon farm during the flowering period is one of the most essential inputs to maximize watermelon production and quality.
\end{abstract}

Keywords: Watermelon, pollinators, honeybees, fruit yield

DOI: $10.7176 / \mathrm{JBAH} / 10-20-02$

Publication date:October $31^{\text {st }} 2020$

\section{Introduction}

Pollination, the transfer of pollen grains from the male organ (anther) of a plant to the female organ (stigma) is helpful to produce the plants and directly links wild ecosystem with agricultural production system. In agriculture, pollination is an important input of crop production, comparable to any other input such as fertilizer, labor or pesticides (McGregor, 1976). Insect pollinators are essential in increasing seed set of many flower and fruit crops; as well as the quality of seed /fruit, early flowering, oil content, pyrethrin content, rubber content and the amount of lavender oil (Free, 1993). As a result the need for insect pollination is becoming popular by agricultural community to increase the productivity of crops. From the six known types of pollination agents (insects, birds, wind, gravity, water and mammals) insects are by far the most important in pollination. The biggest groups of insects for pollination are solitary bees, bumblebees and honeybees (Free, 1993); this is because of their sufficient body hair and their behaviour patterns (Du Toit, 1988). According to Johannsmeier and Mostert, (2001) insects are considered to be responsible for $80-85 \%$ of all pollination, and of this $75-80 \%$ are attributable to honeybees, pollinating one or more cultivars of $66 \%$ of the world's 1500 crop species which is accounting for $15-30 \%$ of food production. In the United States, the annual value of increased agricultural production in yield and quality that is attributed to honeybee pollination varied from US\$9.3 billion in 1989 to US\$14.6 billion in 2000 (Morse and Calderone 2000). In Western Cape (South Africa) the deciduous fruit industry which is entirely dependent on honeybees as pollinators generates R1 billion per year and creates job opportunities for 80,000 people (Picker et al., 2004). The contribution of managed honeybee pollination to crop production and quality has been estimated to be more than the value of honey and wax production (Shrestha, 2004).

Honeybee pollination is one of the most important factors in seed production of agricultural crops (Free, 1971; Gregar, 1984) and improves the genetic makeup of the plant species through cross pollination. It also increases the yield of crops and brings qualitative change in seeds/fruits of many cultivated plants.

Honeybee provides the most favorable condition for selectivity of pollen there by the viability and absolute seed weight increase hence, the seed germination improves. The abundance of pollinators help greater proportion of flowers set seeds earlier resulting more and uniform seeds per flower. Inadequate pollination would lead to low grain and deformed fruits/seeds.

Watermelon (Citrullus lanatus) is a member of the cucurbit family commonly referred to as Cucurbitaceae (Huh, Solmaz \& Sari, 2008); a warm-season crop related to cantaloupe, squash, cucumber and pumpkin (Georage, Darbie \& Kelley, 2000). It is an important horticultural crop, mostly known for its sweet and juicy fruit, grown commercially in areas with long frost-free warm climates all over the world (Jeffrey, 2001; Prohens \& Nuez, 2008). Fruits of watermelon constitute a delicious and refreshing dessert in hot weather serving as an important source of water especially in Kalahari Desert and other arid areas of Africa. Watermelons are excellent sources of 
antioxidant such as lycopene, vitamin $\mathrm{A}$ and vitamin $\mathrm{C}$ that help in preventing cell damage, neutralizing and removing free radicals (USDA, 2009). It is rich in potassium that maintains blood pressure to prevent disease such as stroke and heart disease and might decrease the size of the kidney stone (USDA, 2009).

Watermelon production in Ethiopia is under expansion especially in the central parts of the country and is becoming a very important source of income for small scale farmers in mid rift valley of Ethiopia (Amenti et al., 2009). Its major production restricted to limited areas in Oromia region of east Shoa zone. Though watermelon demand is highly increasing from time to time especially in big cities (Addis Ababa, Adama, etc) as the volume of the fruit in every supermarket is rising in addition to road side marketing. However, the production in quantity and quality of fruit yield was low in the absence of honeybee pollination (Amenti et al., 2009). Watermelon is selfincompatible crops that required honeybees and other insects' for cross-pollination. Each female watermelon flower will need around 500 to 1000 pollen grains to be produce marketable watermelon fruit (Adlerz, 1996). Study also indicated that supplementary pollination by honeybees' increases the percentage of flowers forming fruit per plant and the size of the fruit. In Ethiopia, information on the roles of honeybee pollination watermelon fruit production and quality is limited. Therefore, this study was initiated to see the role of managed honeybee pollination on quantity and quality of watermelon and to identify potential pollinators of watermelon other than honeybees.

\section{Materials and Methods \\ Experimental Site Description}

The experiment was carried out at Adami Tulu Agricultural Research Centre (ATARC) located in Adami Tulu Jido Kombolcha district, East Shoa Zone of Oromia, Ethiopia. Adami Tulu Agricultural Research Center is situated in mid-rift valley, $167 \mathrm{~km}$ south of Addis Ababa on Hawassa road. It lies at latitude of $7^{\circ} 9^{\prime} \mathrm{N}$ and $38^{\circ} 7^{\prime}$ E longitude. It has an altitude of 1650 meters above mean sea level and average annual rainfall is $760.9 \mathrm{~mm}$. Rain fall is bimodal and unevenly distributed that extends from February to September with a dry period in May to June, which separates the preceding short rains from the following long rains. The means maximum and minimum temperatures are $12.6^{\circ} \mathrm{C}$ and $27^{\circ} \mathrm{C}$, respectively. The soil type is fine, sandy loam with sand: silt: clay in the ratio of $34: 38: 18$, respectively. The average $\mathrm{pH}$ of the area is 7.88 (ATARC, 1998).

\section{Experimental setup}

The watermelon was raised with the recommended agronomic package practices. The experiment was conducted under rain fed condition with supplemental irrigation in months with inadequate rains during the production period. Proper site selection was made to minimize risk of pests and disease occurrence, to reduce fertility difference of the experimental plots, flooding and water logging conditions. Land was prepared by digging the ground and smoothing. Good looking seeds with uniform size were planted. The spacing between rows was $2 \mathrm{~m}$ and $1 \mathrm{~m}$ between plants. Five seeds were planted per hole and then thinned to one seeding per hole after two-true leaves to minimize the risk of having vacant hill. The experiment was laid out in Randomized Complete Block Design (RCBD) with three treatments and three replications. Variety of Charleston Gray 33 was used and planted on the plot size of $4 \mathrm{~m} \mathrm{x} 6 \mathrm{~m}\left(24 \mathrm{~m}^{2}\right)$. The three pollination treatments were: plots caged in nets with honeybee (T1), plots caged in nets without any pollinator (T2) and plots open pollinated (T3) were applied.

\section{Data collected}

\section{Fruit yield and quality}

Fruit number per plant, average fruit diameter, average fruit weight, total fruit yield and marketable fruit yield were recorded from six selected plants at first, second and third harvest. Fruit diameter was measured by using caliper from six fruit selected per plot. All fruits ready for harvest were considered as marketable regardless of their fruit length, width and weight except diseased and cracked ones.

\section{Flower visitation assessment}

The bee activity were observed on the plot left open for any pollinator for five consecutive days to assess which and how many insect species were visiting the watermelon plants. Watermelon plants that have approximately above 40 flowers were selected and number of honeybees visiting at these flowers was recorded for 15 minutes at $1 \mathrm{~h}$ interval from 6.00 to $18.00 \mathrm{~h}(7-8 \mathrm{~h}, 9-10 \mathrm{~h}, 11-12 \mathrm{~h}, 13-14 \mathrm{~h}, 15-16 \mathrm{~h}, 17-18 \mathrm{~h})$. In a slow walk along all labeled flowers of treatment, the identity of all insects that visited watermelon flowers was recorded. All insects encountered on flowers were recorded and the cumulated results expressed in number of visits to determine the relative frequency of honeybee.

\section{Germination test}

Observations were also taken on germination percentage of the seeds of all three treatments. For germination potential test 100 seeds of watermelon were sprinkled on a $10 \mathrm{~cm}$ diameter petri plate which was covered with 
moist filter paper. Moisture was maintained by spraying water. The filter paper was removed after the germination was over and the number of seeds germinated out of hundred was counted. The experiment was replicated three times. A germination success study was conducted by considering the principle of maximum percentage germination, following the necessary steps used by the International Rules for Seed Testing (ISTA 2009). Finally germination percentage of seeds was determined by using the following formula:

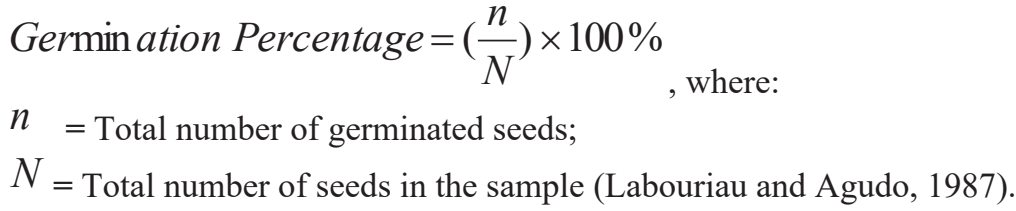

\section{Mass of 1000 seeds and total fruit yield (g) per24 $\mathrm{m}^{2}$ (ytidd from haneybec pollinated - yield from insects excluded)

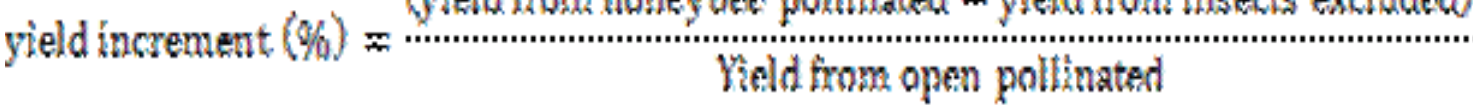

\section{Statistical analysis}

All collected data were subjected to Analysis of Variance (ANOVA) using SAS software (The SAS system for windows 9.0) appropriate to the design of the experiment. Mean separation was done using LSD test at $\mathrm{p}<0.05$.

\section{Results and Discussions}

Under field experiment the effect of honeybee pollination on fruit yield and various yield attributing parameters of watermelon were studied as compared to open pollination and without any pollinator.

\section{Assessment of insect visitors on watermelon flowers}

Various insects belonging to different orders visited watermelon flowers during its flowering time. These include honeybee, butterflies, flies, wasps, moths, Bumblebee and Xylocopa. Amongst the 821 insect visitors recorded on watermelon flowers during the study period, honeybee is the major pollinator of watermelon with 548 visit (67\%) in the open pollination on the field, while moth was the least abundant visitors in the open pollination (table 1).

\section{Fruit diameter}

Maximum fruit diameter $27.9 \mathrm{~cm}$ was recorded in honeybee pollinated plots followed by open pollination $27.3 \mathrm{~cm}$ and caged without honey $22.9 \mathrm{~cm}$ (Table 2). Statistical analysis of data shows significant differences between honeybees pollinated and open pollinated treatments but no statistical significance difference between pollination caged with bees and open. Hossanian et al., (2018) also stated that lower fruit diameter was found in pollination caged without honeybee.

\section{Total fruit yield $(\mathrm{kg} / \mathrm{ha})$}

The findings demonstrated that the yield obtained from plots pollinated by honeybee was superior with the mean yield of $57472 \mathrm{~kg} /$ hectare followed by plots left open under a natural condition with the mean yield of 38361 $\mathrm{kg} /$ hectare. The lowest mean yield of $22472 \mathrm{~kg} / \mathrm{hectare}$ was recorded for the plots excluded insect pollinator (Table 2).Honeybee pollination increases the yield of watermelon fruit by $91 \%$ over the treatment without any pollinator. This indicated how much honeybees are contributing to seed yield increment of this valuable crop. The fruit yield difference between the treatments indicated that the crop requires insect pollination particularly honeybees for fruit production. Delaplane and Mayer, (2014) also stated that, the number of pollen grains deposited on the stigma by pollinators is directly related to seed formation, which often determines fruit size; provide greater fruit yields and treatments without honey bee colony that provided lower water melon, pumpkin and cucumber seed numbers, fruit yields and weights. It has been identified that pollination should be realized by honeybees in $90 \%$ in order to harvest more and higher quality fruits in citrullus lanatus (Ozbek, 2008). Velthuis et al., (2002) also conducted study it has been found that the honeybees provide a significant increase in citrullus lanatus pollination compared to wind and small insects pollination and the highest yield has been obtained from the field allowed free for honeybee entrance.

\section{Average of fruit weight}

Fruits from honeybee pollinated of watermelon were bigger and weighed more compared to those from control watermelon. The average weight of watermelon fruit in honeybee pollinated plots was $7.5 \mathrm{~kg}$ as compared to open pollinated plots $5.2 \mathrm{~kg}$, revealing $44.2 \%$ increase in fruit weight as a result of honeybee pollination while the least $4.37 \mathrm{~kg}$ was recorded for plot received the caged without any pollinator (Table 2). 


\section{Number of seeds per fruit}

The average numbers of seeds produced per fruit of treatments were $587.6 \mathrm{gm}, 525.8 \mathrm{gm}$ and $429.7 \mathrm{gm}$ plots caged with honeybee, caged without any pollinator and open pollination treatments, respectively (Table3). Seeds produce per fruit of watermelon was found to be significantly different between the treatments $(\mathrm{p}<0.05)$. Prakash et al., (2004) found that the number of seeds per fruit and average fruit weight in bee pollinated plants might be attributed to the sufficient number of pollen grains received by the flowers which were best provided by honeybees in caged conditions as compared to caged without bees and open pollination. This also might be due to the adequate pollination done by honeybee inside the cage whereas this study obtained the lowest value in yield in case of without honeybee pollination. Closely related results were reported by Meisels (1997) in a greenhouse experiment involving sweet paper and using bees as pollinators in which the number of seeds per fruits were increased as compared with the control.

\section{0 seeds weight $(\mathbf{g m})$}

Both honeybee and open pollination significantly increased 1000 seeds weight of watermelon with 3.65 gm and $3.5 \mathrm{gm}$, respectively as compared to without any pollinator $2.17 \mathrm{gm}$. An increment of $34 \%$ in 1000 seeds weight of watermelon was obtained by placing honeybee (Apis mellifera) colonies in watermelon fields in comparison to that without any pollinator (Table 3). S.Alan, Bradley and Taylor (2015) also reported that water melon (citrullus lanatus) fruit weights increased when honeybee colonies were included. Natural pollination was insufficient to stimulate maximum fruit size development and seed weight per fruit. Although watermelon (Citrullus lanatus) fruit set will occur with natural pollinators, addition of honeybee colonies will ensure the presence of pollinators to maximize fruit size.

\section{Germination potential}

There were statistically different $(\mathrm{p}<0.05)$ germination percentage among three treatments. Statistically, the highest germination percentage $28.36 \%$ was recorded in caged with honeybee treatment followed by open left treatment $21.57 \%$ while the least $13.60 \%$ germination was in caged treatment without any pollinator (Table 3 ). The increase in germination rate in the open plots is a result of a superior pollinating efficiency of honeybees. Similarly Yücel and Duman (2005) reported that the germination rate was greater on average by $12 \%$ in onion with honeybee activity.

\section{Marketable fruit yield}

The average marketable watermelon fruit yield is $48524 \mathrm{~kg} / \mathrm{ha}$, if caged with honeybees, and $31467 \mathrm{~kg} / \mathrm{ha}$ for plant left open to all insect pollinators. Honeybee pollination increases the yield of marketable watermelon fruit yield by $36.4 \%$ (Table 3 ). The mean yield of marketable fruits matured per plot was statistically significant $(\mathrm{P}<0.05)$.

Table 1: Total number and percentage of various pollinators collected from watermelon during the flowering period.

\begin{tabular}{llll}
\hline Insect order & Common name & No. & Percent (\%) \\
\hline Hymenoptera & Honeybee & 548 & 67 \\
& Bumblebee & 157 & 19 \\
Orthopter & Xylocopa & 61 & 7.4 \\
Dipter & Fly & 24 & 2.9 \\
Lepidopter & Butterfly & 13 & 1.6 \\
& Moth & 7 & 0.9 \\
Orthopter & Wasp & 11 & 1.3 \\
\hline
\end{tabular}

Table 2. Effect of honeybee pollination on yields and yield parameters of watermelon tested at Adami Tulu Agricultural Research Center.

\begin{tabular}{|c|c|c|c|c|}
\hline Treatments & $\begin{array}{l}\text { Fruit yield } / \mathrm{kg}^{-} \\
\text {ha }\end{array}$ & No. fruits & $\begin{array}{l}\text { Average fruit wt } \\
(\mathrm{kg})\end{array}$ & diameter \\
\hline Plants caged with honeybee & $57472 \pm 6.41^{\mathrm{a}}$ & $12.5 \pm 0.78^{\mathrm{a}}$ & $7.50 \pm 0.50^{\mathrm{a}}$ & $27.9 \pm 0.36^{\mathrm{a}}$ \\
\hline Open pollinated & $38361 \pm 4.83^{c}$ & $7.4 \pm 1.20^{\mathrm{c}}$ & $6.0 \pm 0.50^{\mathrm{a}}$ & $27.3 \pm 0.45^{\mathrm{a}}$ \\
\hline $\begin{array}{l}\text { Plants caged without any } \\
\text { pollinator }\end{array}$ & $22472 \pm 2.22^{b}$ & $4.3 \pm 0.99^{b}$ & $4.37 \pm 0.24^{b}$ & $22.9 \pm 0.61^{b}$ \\
\hline $\operatorname{LSD}(5 \%)$ & 38.4 & 1.7 & 0.68 & 1.2 \\
\hline $\mathrm{CV}(\%)$ & 10.24 & 7.36 & 3.21 & 6.08 \\
\hline
\end{tabular}

Means followed by different letters within a column are significantly different at the $5 \%$ level of probability using Tukey Student Test (USD). 
Table 3. Effect of honeybee pollination on seeds set, seeds weight, germination and yield of marketable fruits matured

\begin{tabular}{|c|c|c|c|c|}
\hline Treatments & $\begin{array}{l}\text { No. } \\
\text { seeds/fruit }\end{array}$ & 100 seeds wt.(gm) & Germination (\%) & Marketable fruit $(\mathrm{kg} / \mathrm{ha})$ \\
\hline Plants caged with bee & $587.6 \pm 28.7^{\mathrm{a}}$ & $3.65 \pm 0.25^{\mathrm{a}}$ & $28.36 \pm 3.2^{\mathrm{a}}$ & $48524 \pm 2.85^{\mathrm{a}}$ \\
\hline Open pollinated & $525.8 \pm 15.5^{\mathrm{c}}$ & $3.50 \pm 0.10^{\mathrm{a}}$ & $21.57 \pm 6.5^{\mathrm{c}}$ & $31467 \pm 1.2^{\mathrm{b}}$ \\
\hline Plants caged without bee & $429.7 \pm 32.9^{b}$ & $2.17 \pm 0.00^{\mathrm{b}}$ & $13.60 \pm 2.4^{\mathrm{b}}$ & $13248 \pm 2.52^{\mathrm{c}}$ \\
\hline $\operatorname{LSD}(5 \%)$ & 18.34 & 1.32 & 3.58 & 17.04 \\
\hline $\mathrm{CV}(\%)$ & 3.12 & 13.02 & 3.66 & 4.84 \\
\hline
\end{tabular}

\section{Conclusions and Recommendation}

The study revealed that watermelon (Citrullus lanatus L.) is largely dependent on intensive honeybee pollination. The results of the study also revealed that honeybee pollination increases watermelon fruit yield by $91 \%$ over natural pollination. Therefore, moving honeybee colonies to watermelon farm during the flowering period is one of the most essential inputs to maximize watermelon fruit production and quality. It is important also to create awareness on the value of crop pollination in boosting crop yield and to solve the challenges they are facing.

Acknowledgements: Authors are expressing their heartfelt and deep gratitude to Ethiopian Agricultural Research Institute for funding this research and also Adami Tulu Agricultural Research Centre for providing office and facilitating necessary material for the accomplishment of this study.

\section{References}

Adami Tulu Agricultural Research Center (ATARC).1998. ATARC profile. Oromia Agricultural development Bureau, Addis Ababa, Ethiopia

Alderz, W. C.1996. Honeybee numbers and watermelon pollination. Journal of Economic Entomology, Vol.59, no, 1, pp, 28-30, 1996.

Amenti Chali, Tekalign Gutu, Teshoma Abdissa, and Wole Kinati.2009. Assessment of Watermelon production and utilization in major producing areas of Ethiopia: Challenges and Opportunities. Survey report. Adami Tulu Agricultural Research Center, East Shoa, Ethiopia.12 p.

Delaplane, K.S. and D.F. Mayer. 2014. Crop pollination by bees. CAB Intl., Wallingford, U.K.

Free, J. B. 1993. Insect Pollination of Crops (2nd ed.). San Diego, CA: Academic Press

George, E. B., Darbie, M. G., \& Kelley, W. (2000). Commercial watermelon Production (996th ed.). Georgia: University of Georgia.

Hossain, M. S., F. Yeasmin, M. M. Rahman, S. Akhtar1 and M. A. Hasnat.2018. Role of Insect Visits On Cucumber (Cucumis Sativus L.) Yield, J. biodivers. conserv. bioresour. manag. 4(2), 2018

Huh, Y. C., Solmaz, I., \& Sari, N. (2008). Morphological characterization of Korean and Turkish watermelon. In IXth EUCARPIA meeting on genetics and breeding of Cucurbitaceae (Pitrat M, ed), INRA, Avignon (France), (pp. 327-334). France

Jeffrey, C. (2001). Curcurbitaceae: Mansfield ornamentals. (Hanelt, P. Ed.) (3rd ed.). Berlin, Germany: Springer Publishers.

Johannsmeier, M. F. and Mostert, J. N. 2001. Crop pollination. In: Johannsmeier, M. F. (Ed.), Beekeeping in South Africa, 3rd edition, revised, Plant Protection Research Institute handb.

Kevan, G. P. 1999. Pollinators as bio indicators of the state of the environment: species, activity and diversity. Agriculture, Ecosystems and Environment 74: 373-393.

Morse, R. A. and Calderone, N. W. 2000. The value of honeybees as pollinators of U.S. crops in 2000. Bee Culture 128: $1-15$.

Özbek, H., 2008.Insect Species Visiting Turkey's Temperate Climate Fruit Species Uludağ Bee Magazine, 8(3): 92-103

Picker M,Griffiths C and Weaving A 2004. Field guide to insects of South Africa. Struik Publishers: South Africa.

Prakash, K. B., S. M. Sajjanar, G. Kuberappa, H. P. Prabhuswamy and G. Eswarappa. 2004. Effect of number of bee visits on fruit set and some fruit characters in Cucumis sativus L. Adv. Pollen Spore Res. 22: 127-130.

Prophens, J., \& Nuez, F. (2008). Vegetables. In Handbook of Plant Breeding (1st ed., pp. 381-385). Berlin: Springer Press.

Shrestha J B 2004. Honeybees and Environment. Agriculture and Environment. Gender Equity and Environment Division. Ministry of Agriculture and Cooperatives, HMG, Nepal, pp 1-8.

Suresh,D . h. 2008. Impact of honeybee pollination production of Niger on seed. TOLON

S. Alan Walters and Bradley H. Taylor.2015. Effects of Honey Bee Pollination on Pumpkin Fruit and Seed Yield Hort science 41(2):370-373. 215

USDA. Nutrient Database. Release. 22 (2009). Available at: http://www .ars.usda.gov/services/docs. htm? docid $=8964 \mathrm{htm}$.docid $=8964$. Accessed on July 30, 2020 
Velthuis, H.H., Kevan, P., Imperatriz Fonseca, V., The historical background of the domestication of the bumblebee, bombus terrestris, and its introduction in agriculture, Ministry of Environment, Sao Paulo, Brasil: p. 177184,2002

Yücel B and Duman I 2005. Effects of foraging activity of honeybees (Apis mellifera L.) on onion (Allium cepa) seed production and quality. Pakistan Journal of Biological Sciences 8 (1) 123-126. 